ARTICLE

DOI: $10.1038 / s 41467-018-05814-0$

\title{
Precession-band variance missing from East Asian monsoon runoff
}

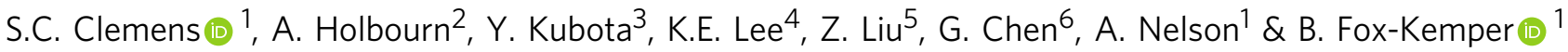

Speleothem $\mathrm{CaCO}_{3} \delta^{18} \mathrm{O}$ is a commonly employed paleomonsoon proxy. However, inferring local rainfall amount from speleothem $\delta^{18} \mathrm{O}$ can be complicated due to changing source water $\delta^{18} \mathrm{O}$, temperature effects, and rainout over the moisture transport path. These complications are addressed using $\delta^{18} \mathrm{O}$ of planktonic foraminiferal $\mathrm{CaCO}_{3}$, offshore from the Yangtze River Valley (YRV). The advantage is that the effects of global seawater $\delta^{18} \mathrm{O}$ and local temperature changes can be quantitatively removed, yielding a record of local seawater $\delta^{18} \mathrm{O}$, a proxy that responds primarily to dilution by local precipitation and runoff. Whereas YRV speleothem $\delta^{18} \mathrm{O}$ is dominated by precession-band ( $23 \mathrm{ky}$ ) cyclicity, local seawater $\delta^{18} \mathrm{O}$ is dominated by eccentricity $(100 \mathrm{ky})$ and obliquity ( $41 \mathrm{ky})$ cycles, with almost no precessionscale variance. These results, consistent with records outside the YRV, suggest that East Asian monsoon rainfall is more sensitive to greenhouse gas and high-latitude ice sheet forcing than to direct insolation forcing.

\footnotetext{
${ }^{1}$ Earth, Environmental, and Planetary Sciences, Brown University, Providence 02912 RI, USA. ${ }^{2}$ Institute of Geosciences, Christian-Albrechts-University, 24118 Kiel, Germany. ${ }^{3}$ Geology and Paleontology, National Museum of Nature and Science, Tsukuba 110-8718, Japan. ${ }^{4}$ Ocean Science, Korea Maritime and Ocean University, Busan 49112, South Korea. ${ }^{5}$ Atmospheric Sciences Program, Department of Geography, The Ohio State University, Columbus 43210 OH, USA. ${ }^{6}$ Institute of Earth Environment, Chinese Academy of Sciences, 710061 Xi'an, China. Correspondence and requests for materials should be addressed to S.C.C. (email: Steven_Clemens@Brown.edu) or to A.H. (email: ah@gpi.uni-kiel.de) or to Y.K. (email: yoshimi@kahaku.go.jp) or to K.E.L. (email: kyung@kmou.ac.kr)
} 
T he study of orbital-scale climate change during the late Pleistocene is unique in that the signal-to-noise ratio is large, the external forcing (insolation) is known, and the critical internal forcings (greenhouse gases and terrestrial ice volume) are extremely well constrained. As such, it should be possible to assess the underlying mechanisms driving climate change at this time scale, as well as the relative sensitivity to these forcings. The orbital time scale $\left(10^{4}\right.$ to $\left.10^{5} \mathrm{yr}\right)$ is also important because the frequency and amplitude of abrupt, centennial, and millennial-scale events may vary with changes in the longer-term mean state ${ }^{1,2}$. Here the focus is on orbital-scale variability in the East Asian Monsoon (EAM), defined as variance concentrated at periods (period $=1$ /frequency) associated with the eccentricity ( $100 \mathrm{ky})$, obliquity $(\sim 41 \mathrm{ky})$, and precession $(\sim 23$ and $\sim 19 \mathrm{ky})$ characteristics of the Earth-Sun orbital geometry ${ }^{3,4}$. Understanding changes in monsoon precipitation as function of changing insolation, global ice-volume, and greenhouse gases is a primary goal of paleoclimate research given the prospect of climate-induced changes in summer-season rainfall impacting agriculture, and food production.

An extensive array of paleomonsoon proxies has been developed and applied throughout the Indian Monsoon and EAM regions in an effort to reconstruct and understand the mechanisms driving changes in rainfall as recorded in loess, lake, cave, and marine archives ${ }^{5-9}$. Most EAM proxy records contain variance associated with eccentricity, obliquity, precession, and heterodynes thereof; usually with the largest concentrations of variance at eccentricity, obliquity, or orbital-associated heterodynes ${ }^{10-12}$. This indicates that the EAM responds strongly to global ice volume and greenhouse gasses ${ }^{9-12}$ (also dominated by eccentricity-band and obliquity-band variance), as well as insolation forcing (dominated by precession-band variance). Heterodyne variance in EAM and other records ${ }^{10}$ arises from incorporation of variance from climatic processes operating at different primary orbital periods ${ }^{13}$ and can be calculated by adding and subtracting primary orbital frequencies (frequency $=$ $1 /$ period). For example, the interaction of variance at eccentricity periods of 130.6, 123.8, 98.7, and $94.7 \mathrm{ky}$ with obliquity at $41.1 \mathrm{ky}$ yields heterodyne spectral peaks at periods ranging from 28.7 to $31.3 \mathrm{ky}$ and from 60 to $72.6 \mathrm{ky}$ (e.g., $1 / 98.7 \pm 1 / 41.1=1 / 29$ and 1/70.4).

A primary exception is the composite speleothem $\delta^{18} \mathrm{O}$ record from the Yangtze River Valley (YRV), characterized by a spectrum almost exclusively dominated by precession-band variance $^{14,15}$. This unique, exceptionally well-dated record and associated spectrum have been interpreted as reflecting East Asian summer-monsoon rainfall, varying dominantly and directly in response to changes in northern hemisphere summer insolation ${ }^{14-16}$, with little influence from global ice volume and greenhouse gasses. A great deal of effort has been spent testing this hypothesis, with a particular focus on the extent to which the YRV speleothem $\delta^{18} \mathrm{O}$ record $\left(\delta^{18} \mathrm{O}_{\text {cave }}\right)$ should be interpreted as East Asian rainfall amount ${ }^{17-19}$, upstream changes in evaporative source regions, moisture transport paths, and evaporation and condensation processes along the transport path $8,9,20-26$, or changes in seasonality and frontal position ${ }^{27-29}$. Beyond largescale ocean and atmospheric processes, cave ventilation seasonality $^{30}$ and soil zone and epikarst dynamics ${ }^{31,32}$ have been discussed as well, including threshold processes associated with abrupt changes in soil evaporation and water flow through the soil horizon ${ }^{25,33}$.

Here four new highly-resolved records from International Ocean Discovery Program (IODP) Site U1429 in the East China Sea (ECS) are presented and used to reconstruct local seawater $\delta^{18} \mathrm{O}\left(\delta^{18} \mathrm{O}_{\mathrm{sw}}\right)$, a parameter known to vary linearly with salinity; in this case varying as a function of YRV runoff and direct precipitation to the ECS. The ECS planktonic foraminifer $\delta^{18} \mathrm{O}$ record replicates, to an extraordinary degree, the precession- and sub-orbital-scale variance found in onshore $\delta^{18} \mathrm{O}_{\text {cave }}$. However, when corrected for the effects of changing local temperature and global seawater $\delta^{18} \mathrm{O}$, the resulting local $\delta^{18} \mathrm{O}_{\text {sw }}$ record lacks significant precession-band variance, in contrast to the precession-dominated YRV $\delta^{18} \mathrm{O}_{\text {cave }}$ spectrum. Instead, local $\delta^{18} \mathrm{O}_{\mathrm{sw}}$ is dominated by eccentricity- and obliquity-band variance as well as two heterodynes predicted by interaction of processes operating at these bands. The $\delta^{18} \mathrm{O}_{s w}$ spectrum is consistent with records across the EAM region ${ }^{9-12,34}$ that are also dominated by 100-, 41-, and heterodyne-derived variance, indicating that EAM variability is not driven dominantly and directly by insolation forcing, but is sensitive to internal forcing associated with changes in global-scale ice volume and greenhouse gas forcing ${ }^{10,11,34}$.

\section{Results}

Oceanography and climatology. Site U1429 $\left(31.62^{\circ} \mathrm{N}, 129^{\circ} \mathrm{E}\right.$, $732 \mathrm{mbsl})^{35}$ is located at the north end of the Okinawa Trough (Fig. 1). Winters are characterized by cool sea surface temperature (SST) and strong winds $\left(\sim 18^{\circ} \mathrm{C}, 5-7 \mathrm{~ms}^{-1}\right)$ while summers are characterized by warm SST and weak winds $\left(\sim 28^{\circ} \mathrm{C}, 1-2 \mathrm{~ms}^{-1}\right)^{36}$. The surface moisture balance (precipitation minus evaporation; $\mathrm{P}-\mathrm{E}$ ) is positive in the summer and negative in the winter, consistent with seasonal differences in insolation, winds, and precipitation. Surface water salinity is also seasonal, due to increased $\mathrm{P}-\mathrm{E}$ and YRV summer runoff. Modern salinity at Site U1429 ranges from 33.5 in the summer to 34.7 in the winter ${ }^{37}$ and is very highly correlated with rainfall over the YRV (Fig. 1). This strong correlation extends to the interannual scale as well; YRV flood and drought conditions related to El Niño and La Niña variability can alter salinity by +1 and -6 psu (respectively) out to $500 \mathrm{~km}$ offshore 38 and are accompanied by interannual variability in chororphyll- $a^{39}$. These observations are consistent with strong correlation $(r>0.97)$ of seawater $\delta^{18} \mathrm{O}$ with chlorinity and salinity, which indicate nearcomplete mixing of Yangtze River outflow and ocean waters in the estuary ${ }^{40}$ and in the eastern ECS ${ }^{41}$.

The strong link between modern YRV rainfall and offshore salinity extends into the geological past as well. Kubota et al. ${ }^{42}$ reconstructed the mid-Holocene (7 Ka BP) to present freshwater budget for the U1429 region, employing Heshang cave $\delta^{18} \mathrm{O}$ as a proxy for the isotopic composition of the freshwater end member. They found that local seawater $\delta^{18} \mathrm{O}$ and river discharge have similar responses (no change in the mean) from $7 \mathrm{Ka}$ to present whereas Heshang $\delta^{18} \mathrm{O}$ indicates a $2.5 \%$ increase, a trend previously interpreted to represent decreased rainfall ${ }^{43}$ This finding, no systematic reduction in monsoon rainfall from the mid-Holocene to present, is consistent with a range of independent and diverse rainfall proxies from the EAM region ${ }^{26}$ and indicates a decoupling of YRV precipitation amount and precipitation $\delta^{18} \mathrm{O}$ in the past.

Air mass backtrack trajectory analysis indicates both continental and marine moisture sources to the YRV during the modern summer and winter seasons, with $59 \%$ of precipitation falling during the summer monsoon months (June through September; Supplementary Fig. 1) ${ }^{27}$. Detailed analysis of YRV moisture sources ${ }^{44}$ indicates that the contribution of moisture from land roughly equals that from the Pacific and Indian Oceans combined during both summer (May-September) and winter (October-April). The relative contributions of modern continental and marine moisture sources over the course of the seasonal cycle, weighted by their isotopic composition, successfully replicates modern cave calcite $\delta^{18} \mathrm{O}$ in the EAM region $^{27}$. 

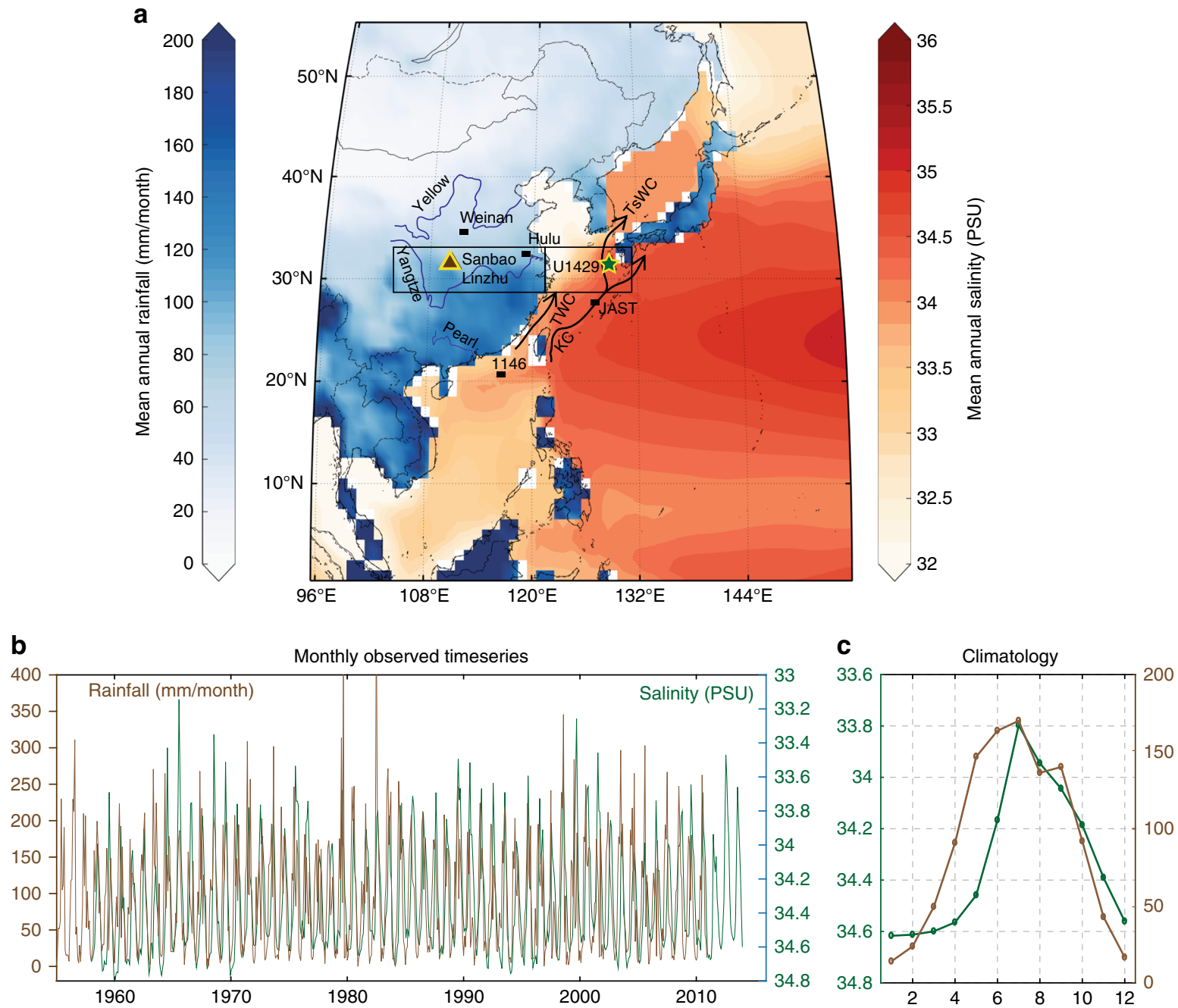

Fig. 1 Modern precipitation and salinity climatologies, rivers, and surface currents. a Locations of IODP Site U1429 and sediment trap site JAST-0148 in the East China Sea. $\delta^{2} \mathrm{H}_{\text {wax }}$ records precipitation isotopes from the Pearl River Valley ${ }^{34}$ and the Loess Plateau ${ }^{10}$, deposited at IODP Site 1146 and Weinan, respectively. Boxes are area averages for CCSM3 model results. Kuroshio current (KC) and Tsushima warm current (TsWC) split south of U142990, 91 Taiwan warm current (TWC) enters from the south. Sanbao, Linzhu, and Hulu caves are the locations from which the composite $\delta^{18} \mathrm{O}_{\text {cave }}$ record was constructed ${ }^{15}$. b Modern rainfall in the Yangtze River Valley (brown) is highly correlated to salinity at East China Sea Site U1429 (green). At the annual cycle with the lag removed, $r=0.89$ and the result is significant at $p<0.01$. c Monthly climatology from b. Salinity from ORAS4 ${ }^{92}$. Rainfall from GPCC ${ }^{93}$. Base-map created using commercially available MATLAB software

Precipitation $\delta^{18} \mathrm{O}\left(\delta^{18} \mathrm{O}_{\text {precip }}\right)$ values reflect the origin, temperature, humidity and transport history of the water vapor $^{31}$. These factors are significantly different for terrestrial and marine air masses contributing to modern EAM rainfall during summer and winter ${ }^{40,45}$. Analysis of cave drip water ${ }^{32}$ indicates that $\delta^{18} \mathrm{O}_{\text {precip }}$ variability in the modern monsoon region of China cannot be explained by either temperature or precipitation alone, likely due to the multiple interacting vapor sources. In addition, Liu et al. ${ }^{46}$ examined the Global and Chinese Network of Isotopes in Precipitation (GNIP and CHNIP) finding that $\delta^{18} \mathrm{O}_{\text {precip }}$ in the YRV region is best related to water vapor content of the atmosphere; the amount effect is minor. Hence, there is little evidence, at least from modern data, that EAM water-isotope proxies can be interpreted directly as indicators of local rainfall amount. For these reasons, reconstructing ECS local $\delta^{18} \mathrm{O}_{s w}$ is important, providing an independent proxy indicator of changes in ECS salinity, varying as a function of precipitation and runoff.
Water-isotope proxy drivers. The oxygen isotopic composition of ECS planktonic foraminifer $\left(\delta^{18} \mathrm{O}_{\mathrm{pf}}\right)$ and YRV $\delta^{18} \mathrm{O}_{\text {cave }}$ have a number of drivers in common as well as a number of drivers that influence each independently (Supplementary Fig. 2). Both records reflect global-scale changes in source water $\delta^{18} \mathrm{O}$ as well as local $\delta^{18} \mathrm{O}_{\text {precip }}$ since both are under the influence of the EAM, and linked by YRV runoff. Changes in surface temperature, in contrast, may be expressed differently in these two proxies. The dominant impact on $\delta^{18} \mathrm{O}_{\mathrm{pf}}$ will be changes in the temperature of calcite precipitation; the impact of evaporation will be minimal because precipitation plus runoff dominates over evaporation in the ECS, where annual average salinity values range between 30 near the coast and 34.5 offshore, out to $130^{\circ} \mathrm{E}^{47}$. Changes in temperature affect $\delta^{18} \mathrm{O}_{\text {precip }}$ and can also be propagated into the cave environment, influencing the temperature of calcite precipitation. Temperature may also have a significant influence through changes in soil zone evaporation and evaporation in the cave atmosphere itself ${ }^{30,31}$. Duan et al. ${ }^{32}$. monitored monthly to bi-monthly $\delta^{18} \mathrm{O}_{\text {precip }}$ and cave drip water $\delta^{18} \mathrm{O}\left(\delta^{18} \mathrm{O}_{\mathrm{dw}}\right)$ at 

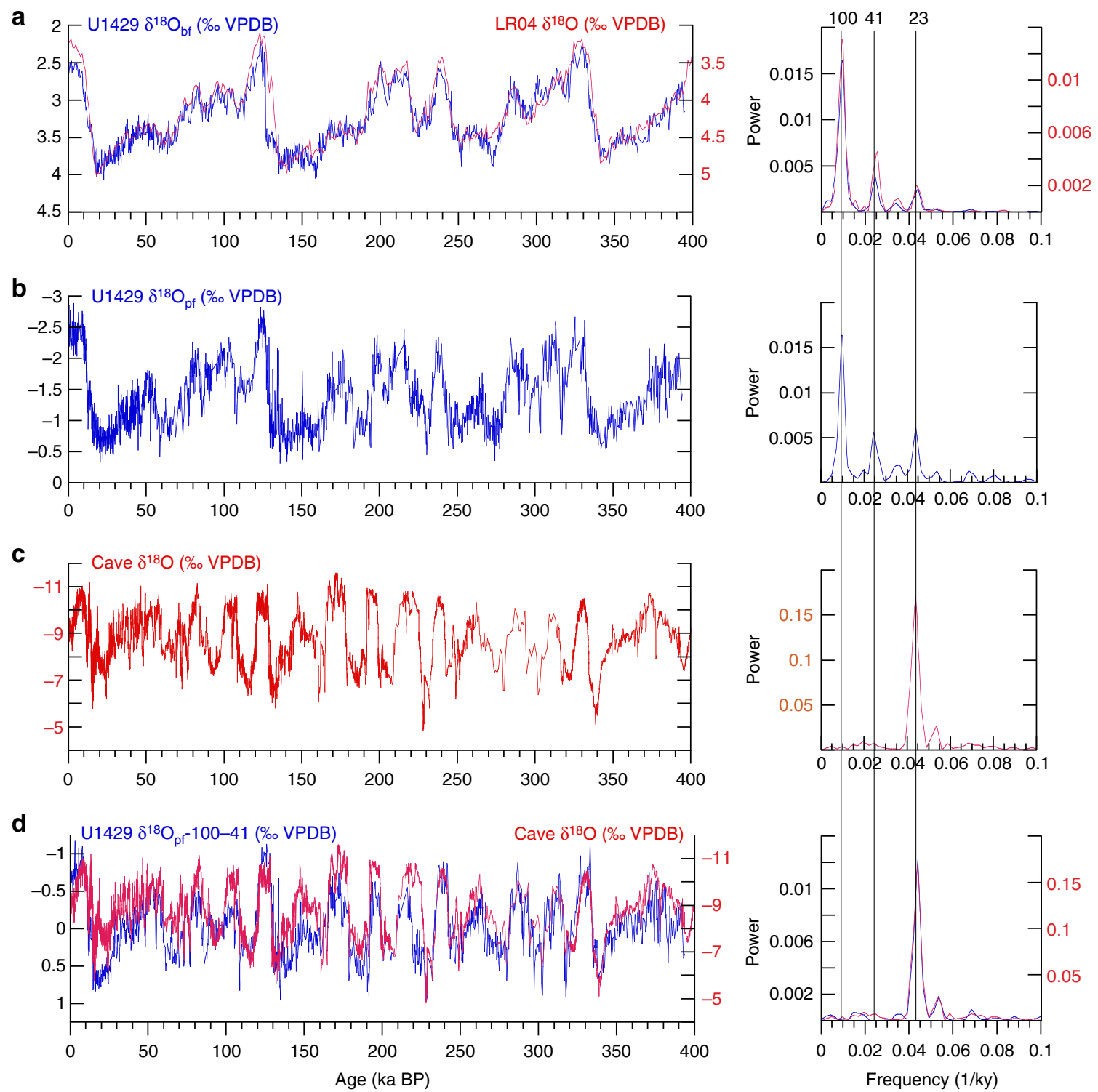

Frequency $(1 / \mathrm{ky})$

Fig. 2 Proxy time series and spectra. a U1429 $\delta^{18} \mathrm{O}_{\text {bf }}$ mapped to the benthic chronology ${ }^{52}$. b U1429 $\delta^{18} \mathrm{O}_{\mathrm{pf}}$ on the benthic age model. c $\delta^{18} \mathrm{O}_{\text {cave }}{ }^{15}$, d Notched $\delta^{18} \mathrm{O}_{\mathrm{pf}}$ mapped to $\delta^{18} \mathrm{O}_{\text {cave. }}$. Labeled dashed lines denote primary orbital frequencies (frequency $=1 /$ period in $\mathrm{ky}$ )

34 sites in the cave region of China to evaluate the impact of processes in the soil, epikarst, and cave environment. They found that $82 \%$ of the drip sites showed little variation in $\delta^{18} \mathrm{O}_{\mathrm{dw}}$ throughout the 3-year study, indicating that $\delta^{18} \mathrm{O}_{\text {cave }}$ incorporates multi-year average signals modulated by seasonally changing recharge and evaporation regimes. Twelve percent of the drip sites recorded damped seasonal to monthly $\delta^{18} \mathrm{O}_{\mathrm{dw}}$, compared to $\delta^{18} \mathrm{O}_{\text {precip. }}$. Six percent fell between the two extremes, with constant, low $\delta^{18} \mathrm{O}_{\mathrm{dw}}$ during the wet season and variable, relatively high $\delta^{18} \mathrm{O}_{\mathrm{dw}}$ in the dry season, thought to result from flow switching in the karst or evaporation within the cave. James et al. $^{30}$ made the case that seasonal cave ventilation is an important driver of cave-air $\mathrm{CO}_{2}$ and hence calcite precipitation; the result being that speleothems from temperate and boreal regions, for example, can be biased toward cool-season calcite precipitation. None of these factors impact $\delta^{18} \mathrm{O}_{\mathrm{pf}}$, calcite precipitated by planktonic foraminifers in the offshore surface environment.

Similarly, biases independent of those impacting $\delta^{18} \mathrm{O}_{\text {cave }}$ can impact ECS $\delta^{18} \mathrm{O}_{\mathrm{pf}}$. Sediment trap results from the Okinawa
Trough indicate that Globigerinoides ruber specimens in the size fraction used for this study (Methods) are reduced in abundance between December and March, potentially introducing a seasonal bias $^{48}$. Site U1429 is located at the bifurcation point of the Kuroshio Current and Tsushima Warm Current ${ }^{49,50}$; variability in these current regimes could impact $\delta^{18} \mathrm{O}_{\mathrm{pf}}$, although the path of the Kuroshio appears stable with regard to glacial sea level changes $^{51}$. Migration of the shoreline closer to Site U1429 during glacial-age sea level low stands ( $120 \mathrm{~m}$ isobath, Supplementary Fig. 3) may alter the delivery and extent of mixing between ${ }^{18} \mathrm{O}$ enriched seawater from the Kuroshio Current with ${ }^{18} \mathrm{O}$-depleted river water at Site U1429. The relative influences of these various independent $\delta^{18} \mathrm{O}_{\mathrm{pf}}$ and $\delta^{18} \mathrm{O}_{\text {cave }}$ drivers may vary at different time scales.

Foraminifera $\delta^{\mathbf{1 8}} \mathbf{O}$. The U1429 benthic foraminifer $\delta^{18} \mathrm{O}$ $\left(\delta^{18} \mathrm{O}_{\mathrm{bf}}\right)$ record was mapped to the global benthic isotope stack ${ }^{52}$ to produce a traditional benthic age model (Methods, Fig. 2a). Cross-spectral analysis indicates high coherence and near-zero 

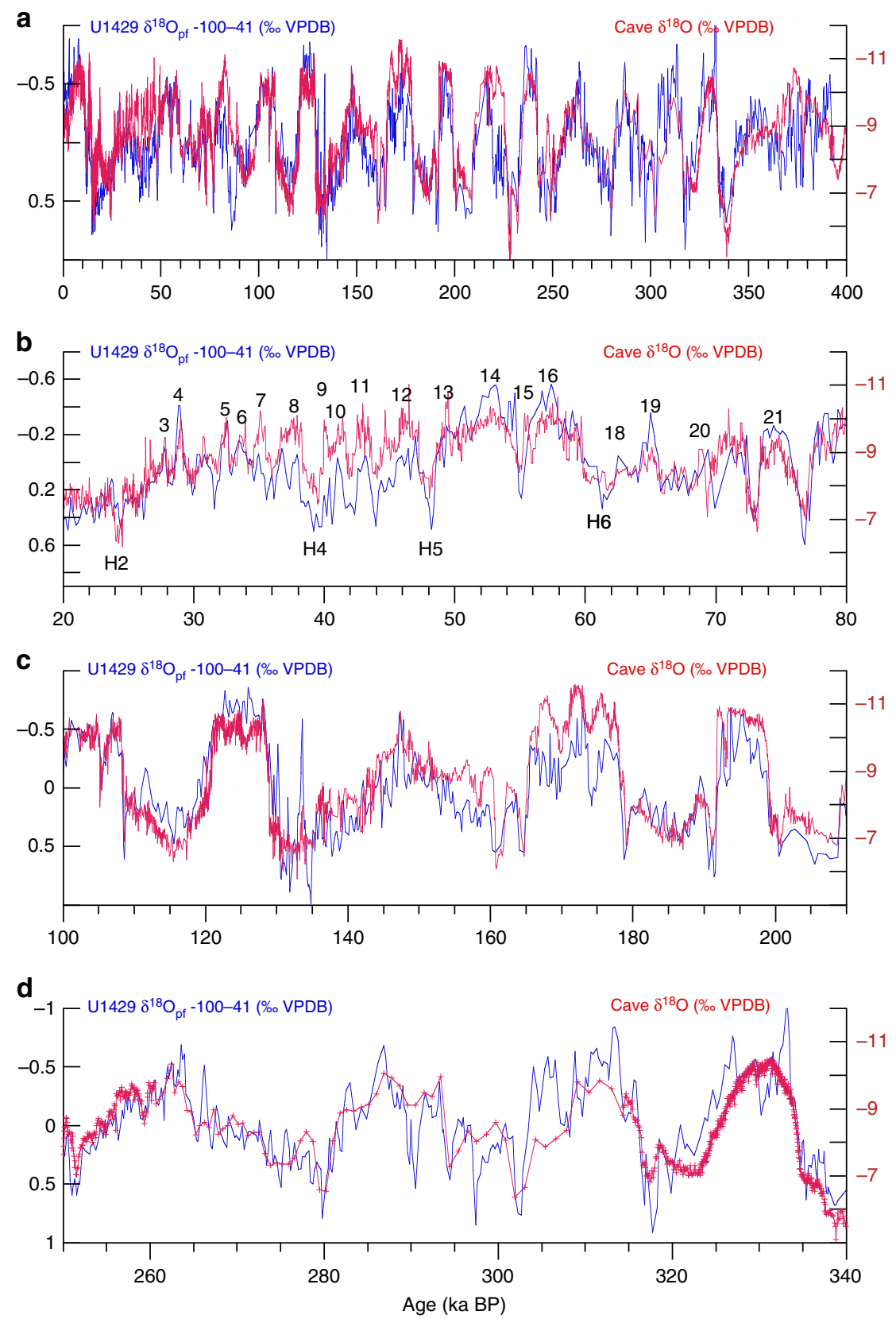

Fig. 3 Millennial-scale structure in notched $\delta^{18} \mathrm{O}_{\mathrm{pf}}$ compared to $\delta^{18} \mathrm{O}_{\text {cave }}$ a Notched U1429 $\delta^{18} \mathrm{O}_{\mathrm{pf}}$ on the cave-based age model. b Expanded $20-80 \mathrm{ka}$ interval with millennial-scale Dansgaard-Oeschger (DO) and Heinrich events numbered. c Expanded 100-210 ka interval. d Expanded 250-340 ka interval showing structure not previously resolved in $\delta^{18} \mathrm{O}_{\text {cave }}$

phase across the Earth-orbital eccentricity, obliquity, and precession bands, verifying the U1429 chronostratigraphy (Supplementary Fig. 4).

The $\mathrm{U} 1429 \delta^{18} \mathrm{O}_{\mathrm{pf}}$ time series is dominated by eccentricity with lesser, sub-equal variance in the obliquity bands and precession bands (Fig. 2b). In contrast, YRV $\delta^{18} \mathrm{O}_{\text {cave }}{ }^{15}$ is dominated by precession-band variance (Fig. 2c), a primary reason why the EAM has been interpreted as a system responding dominantly and directly to northern hemisphere summer-insolation forcing ${ }^{5,14}$. The very strong degree to which $\delta^{18} \mathrm{O}_{\text {cave }}$ variance is also embedded in offshore $\delta^{18} \mathrm{O}_{\mathrm{pf}}$ is illustrated by notch filtering $\delta^{18} \mathrm{O}_{\mathrm{pf}}$ (removing eccentricity- and obliquity-band variance) and then mapping the sub-orbital structure to $\delta^{18} \mathrm{O}_{\text {cave }}$, creating a cave-based age model (Methods); all further analyses use the cave-based age model. Notched $\delta^{18} \mathrm{O}_{\mathrm{pf}}$ (Fig. 2d) demonstrates that the precession-band structure in YRV $\delta^{18} \mathrm{O}_{\text {cave }}$ resides in $\delta^{18} \mathrm{O}_{\mathrm{pf}}$ as well; the spectra are nearly indistinguishable. This strong orbital-scale correspondence is not due to fine-tuning the benthic age model by correlating the notched $\delta^{18} \mathrm{O}_{\mathrm{pf}}$ to $\delta^{18} \mathrm{O}_{\text {cave; }}$; the cave-based age model is spectrally indistinguishable from the benthic age model (Supplementary Fig. 4 ). $\delta^{18} \mathrm{O}_{\mathrm{bf}}$ on the two age models is highly coherent $(0.99 \mathrm{CI})$ with near-zero phase at the eccentricity $(0.08 \pm 0.35 \mathrm{ky})$, obliquity $(-0.23 \pm 0.29 \mathrm{ky})$ and precession $(0.23 \pm 0.17 \mathrm{ky})$ bands.

The strong similarities extend to the sub-orbital scale as well. $\delta^{18} \mathrm{O}_{\mathrm{pf}}$ and $\delta^{18} \mathrm{O}_{\text {cave }}$ have the same millennial-scale structure during both glacial and interglacial intervals (Fig. 3b, c), including Heinrich and Dansgaard-Oeschger events. Finally, U1429 $\delta^{18} \mathrm{O}_{\mathrm{pf}}$ has enhanced resolution of sub-orbital-scale structure within the interval 250 to $340 \mathrm{ka}$ where $\delta^{18} \mathrm{O}_{\text {cave }}$ is less resolved or smoothly 

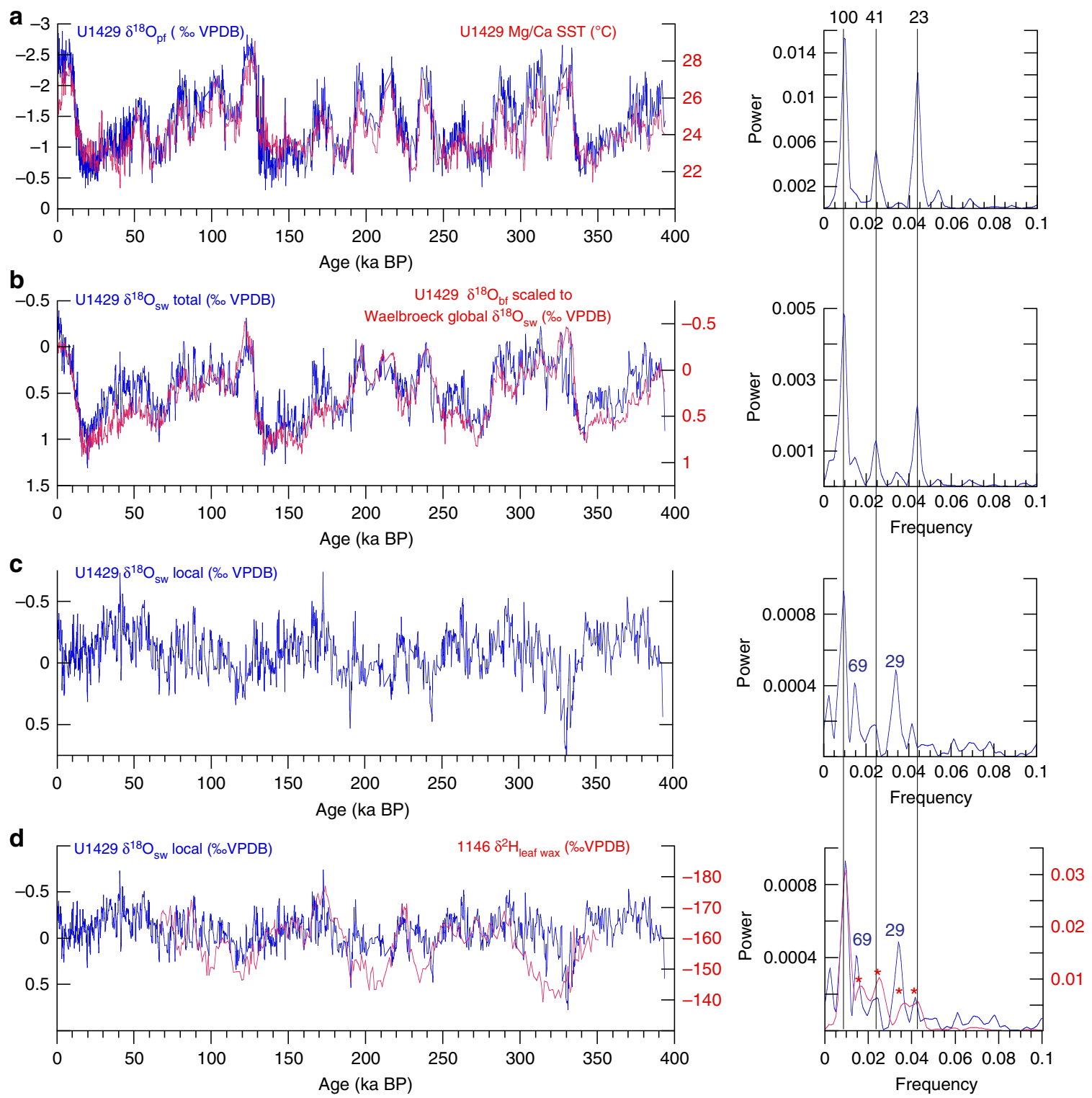

Fig. 4 Time series used in deriving local $\delta^{18} \mathrm{O}_{\text {sw, }}$ and associated spectra. a U1429 $\delta^{18} \mathrm{O}_{\mathrm{pf}}$ (and spectrum) with Mg/Ca SST, both derived from G. ruber (250-355 $\mu \mathrm{m}$ size fraction). b U1429 total $\delta^{18} \mathrm{O}_{\mathrm{sw}}$ (and spectrum) with U1429 $\delta^{18} \mathrm{O}_{\mathrm{bf}}$ scaled to match the global $\delta^{18} \mathrm{O}_{\mathrm{sw}}$ curve $\mathrm{c}^{74}$; this approach preserves the age model and high temporal resolution of the U1429 data. c, d U1429 local $\delta^{18} \mathrm{O}_{s w}$ (and spectrum) with the Pearl River Valley $\delta^{2} \mathrm{H}_{\text {wax }}$ record (and spectrum) from Site $1146^{34}$. Labeled dashed lines denote primary orbital frequencies (frequency =1/period in ky). Orbital-scale peaks for frequencies $<0.05$ labeled with * do not meet the $p=0.05$ threshold level for probability of chance occurrence (Methods)

varying (Fig. 3d). Strong similarities at the orbital (precession) and sub-orbital (millennial) scales confirm that $\delta^{18} \mathrm{O}_{\mathrm{pf}}$ and $\delta^{18} \mathrm{O}_{\text {cave }}$ share common drivers at these time scales, both likely monitoring the $\delta^{18} \mathrm{O}$ of local precipitation; potential biases that impact each of the two proxies independently are not apparent in these records.

Seawater $\delta^{\mathbf{1 8}} \mathbf{O}$. From a climate change standpoint, however, reconstruction of rainfall amount is an important goal. Interpretation of water-isotope proxies as rainfall amount has been a point of contention given that modern data, described above, show that $\delta^{18} \mathrm{O}_{\text {precip }}$ and rainfall amount are uncorrelated in the YRV region. This is addressed by quantitatively removing the effects of changing sea surface temperature (SST) and global seawater $\delta^{18} \mathrm{O}$ from $\delta^{18} \mathrm{O}_{\mathrm{pf}}$ (Methods, Supplementary Note 1). This yields a record of local $\delta^{18} \mathrm{O}_{\mathrm{sw}}$, a proxy that is linearly related to salinity ${ }^{42,53,54}$, responding strongly to YRV runoff as well as direct precipitation to the $\mathrm{ECS}^{41}$.

Removing the SST signal from $\delta^{18} \mathrm{O}_{\mathrm{pf}}$ (Fig. 4a) yields the total $\delta^{18} \mathrm{O}_{\text {sw }}$ (Fig. 4b). Removing global seawater $\delta^{18} \mathrm{O}$ from total $\delta^{18} \mathrm{O}_{\mathrm{sw}}$ (Fig. 4b) yields local $\delta^{18} \mathrm{O}_{\mathrm{sw}}$ (Fig. 4c). In contrast to $\delta^{18} \mathrm{O}_{\text {cave, local }} \delta^{18} \mathrm{O}_{\text {sw }}$ has almost no precession-band variance. Instead, it is dominated by variance at primary orbital periods, including $100 \mathrm{ky}$ (eccentricity), $41 \mathrm{ky}$ (obliquity), and both heterodynes thereof ( 29 and $69 \mathrm{ky}$ ). While this spectral structure is very different from that of YRV $\delta^{18} \mathrm{O}_{\text {cave }}$, it shares strong similarities with precipitation-isotope records to the north and south as well as with global-scale changes in $\mathrm{CO}_{2}, \mathrm{CH}_{4}$, and terrestrial ice volume (Fig. 5a-c).

The eccentricity-band (100 ky) variance in local $\delta^{18} \mathrm{O}_{\mathrm{sw}}$ is coherent $(0.92 \mathrm{CI})$ and near-zero phase $(4 \pm 2 \mathrm{ky})$ with the Site 1146 (Pearl River) $\delta^{2} \mathrm{H}_{\text {wax }}$ record ${ }^{34}$ located $\sim 1000 \mathrm{~km}$ south of the YRV; both are dominated by 100 ky eccentricity-band variance with little 


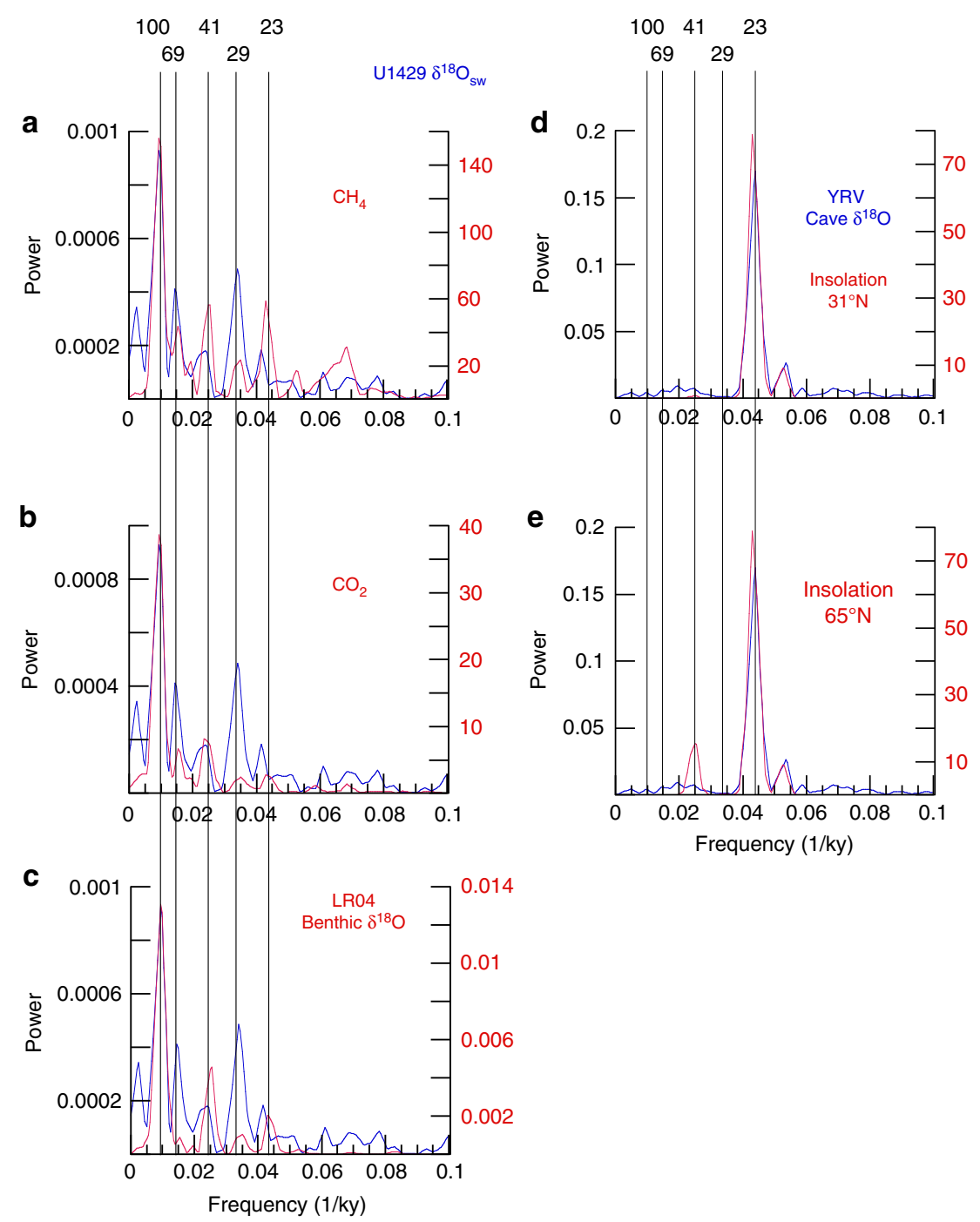

Fig. 5 Spectral comparisons of EAM proxy records with global ice volume, greenhouse gases, and insolation. Local $\delta^{18} \mathrm{O}_{\text {sw, }}$ a record for which the effects of temperature and seawater $\delta^{18} \mathrm{O}$ have been removed, compared to a global $\mathrm{CH}_{4}$, $\mathbf{b}$ global $\mathrm{CO}_{2}$, and $\mathbf{c}$ global ice volume. $\delta^{18} \mathrm{O}_{\text {cave, }}$ a record for which the effects of temperature and seawater $\delta^{18} \mathrm{O}$ have not been removed, compared to $\mathbf{d}$ local summer and $\mathbf{e}$ high-latitude summer-insolation forcing. Labeled lines denote primary orbital frequencies (frequency $=1 /$ period in $\mathrm{ky}$ )

to no precession-band variance (Fig. 4d). The Site 1146 record dominantly reflects input from the Pearl River but has contributions from Taiwan and Luzon as well ${ }^{10,55}$. The heterodyne periods (29 and $69 \mathrm{ky})$ are consistent as well with the 31- and 72-ky heterodynes that dominate variance in the Lantian-Weinan loess $\delta^{2} \mathrm{H}_{\text {wax }}$ record $^{10} \sim 300 \mathrm{~km}$ north of the YRV.

Transient model simulations. Seasonality and the extent to which the local $\delta^{18} \mathrm{O}_{\text {sw }}$ proxy is consistent with model rainfall simulations is assessed by comparison with results from a 300,000 year long accelerated transient climate simulation using the Community Climate Systems Model version 3.5 (CCSM3) $^{56}$. The CCSM3 simulation (Methods, Supplementary Note 2) was run with varying orbital insolation, greenhouse gasses, ice volume, and sea level, following methods and boundary conditions detailed in Chen et $\mathrm{al}^{57}$, in order to capture the climate response to transient forcing ${ }^{57,58}$. EOF comparison of the model and modern EAM precipitation fields for summer and winter seasons are consistent with one another (Supplementary Fig. 5). These simulation result$s$ have been previously used in the EAM region to assess the transient response to changing surface temperature and monsoon precipitation $^{10,59}$
Having removed the effects of surface temperature and global seawater $\delta^{18} \mathrm{O}$ from $\delta^{18} \mathrm{O}_{\mathrm{pf}}$, the result (local $\delta^{18} \mathrm{O}_{\mathrm{sw}}$ ) is compared to model precipitation. Both the YRV and ECS regions (Fig. 1) were evaluated for monthly maximum (summer), minimum (winter), and annual average precipitation in order to assess spatial and seasonal variability. The local $\delta^{18} \mathrm{O}_{\mathrm{sw}}$ heterodyne variance at the 29- and 69-ky periods is unique to the YRV annual average model precipitation field (Fig. 6), suggesting it is transmitted to the ECS via runoff. The 100-ky variance is found in all three (maximum, annual average, and minimum) ECS precipitation records, indicating decreased precipitation during glacial intervals. The same set of proxy-model comparisons was conducted for YRV $\delta^{18} \mathrm{O}_{\text {cave, }}$, including model temperature since the impact of changing local temperature is unknown. $\delta^{18} \mathrm{O}_{\text {cave }}$ is well matched to model YRV surface temperature maximum and precipitation maximum (Supplementary Fig. 6). Hence, the degree to which changes in local temperature or precipitation drive YRV $\delta^{18} \mathrm{O}_{\text {cave }}$ cannot be differentiated with these data. More in-depth interpretation of $\delta^{18} \mathrm{O}_{\text {cave }}$ and local $\delta^{18} \mathrm{O}_{\text {sw }}$ would benefit from isotope-enabled transient model simulations that incorporate realistic greenhouse gas, ice volume, and sea level boundary conditions. 

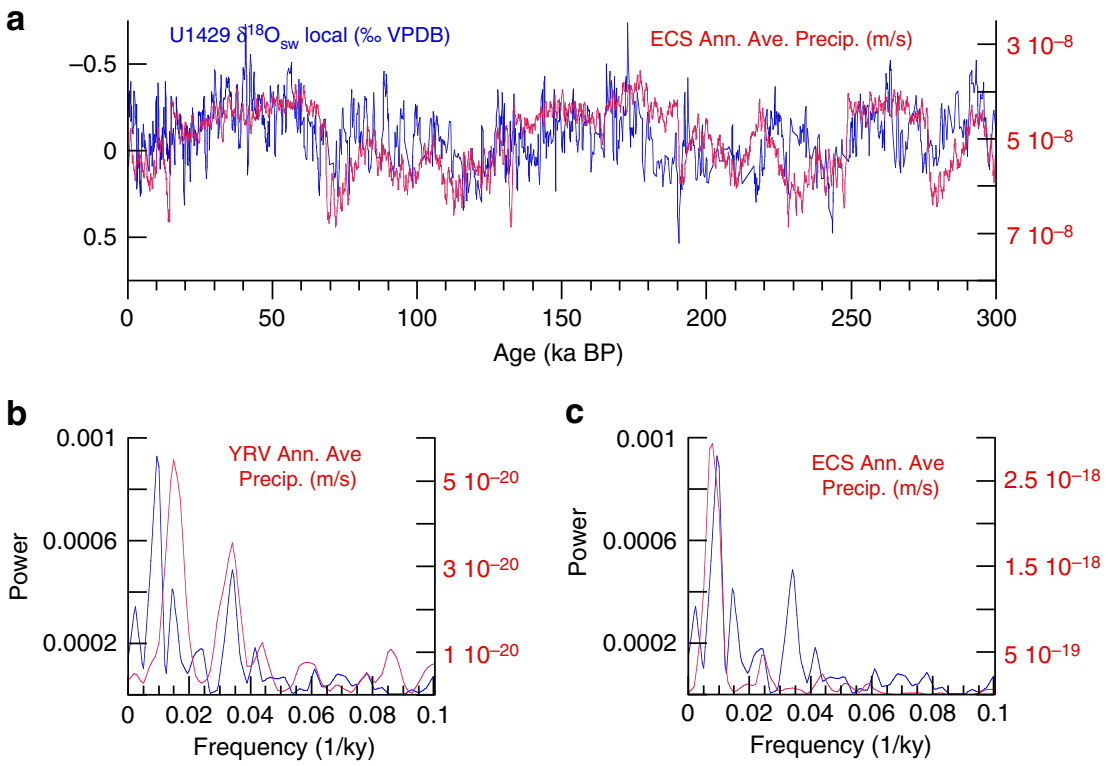

Fig. 6 Comparison of model (annual average, red) and U1429 (blue) time series and spectra. a U1429 local $\delta^{18} \mathrm{O}_{\text {sw }}$ and East China Sea (ECS) model annual average precipitation. The U1429 record is consistent with $\mathbf{b}$ annual average precipitation over the Yangtze River Valley (YRV) accounting for the 29- and 69-ky variance and c ECS annual average precipitation, accounting for the 100- and 41-ky variance. Supplementary Figure 6 shows comparisons of $\delta^{18} \mathrm{O}_{\text {cave }}$ (for which temperature has not been removed) with model temperature and precipitation (monthly annual, maximum, and minimum)

\section{Discussion}

At the eccentricity band, light U1429 $\delta^{18} \mathrm{O}_{\text {sw }}$ and Pearl River Valley $\delta^{2} \mathrm{H}_{\text {wax }}$ occur during glacial intervals (Fig. 4d). Light glacial-age $\delta^{2} \mathrm{H}_{\text {wax }}$ may result from rainout over the emergent continental shelf resulting in lighter inland precipitation isotopes, increased rainout along the moisture transport path (including the emergent Sunda Shelf ${ }^{60}$, changes in glacial-age source water locations, or cooler local precipitation condensation temperatures. Differentiation among these possible mechanisms, or some combination thereof, is not possible at this time but will benefit from rapidly evolving isotope-enabled simulations that incorporate realistic changes in boundary conditions, including icevolume and sea level. Interpreted in the context of salinity (rainfall and YRV runoff), the $100-\mathrm{ky}$ variance in the local $\delta^{18} \mathrm{O}_{\mathrm{sw}}$ signal is likely influenced by shoreline migration, bringing the YRV freshwater source closer to the site during glacial sea level low stands ${ }^{61}$, counteracting the effect of decreased precipitation indicated by an array of independent proxy records of EAM rainfall ${ }^{11,26,62}$ and model simulations ${ }^{63-65}$.

Heterodyne variance in U1429 and in the Lantian-Weinan section to the north likely reflect interactions of variance associated with eccentricity and obliquity forcing as described in Thomas et al. ${ }^{10}$. Thomas et al. note a significant difference in the spectral structure of East Asian water-isotope proxy records $\left(\delta^{18} \mathrm{O}_{\text {cave }}\right.$ and $\left.\delta^{2} \mathrm{H}_{\text {wax }}\right)$ relative to those of loess-based summer monsoon (magnetic susceptibility) and winter monsoon (grain size) proxy records ${ }^{26}$. The loess-based records, also including $\delta^{13} \mathrm{C}$ of inorganic carbonate $\mathrm{e}^{11}$ and an array of isotopic ${ }^{12}$ and magnetic property proxies $9,26,62$ for summer monsoon precipitation are dominated by primary orbital periodicity (eccentricity, obliquity, and precession). The water-isotope proxies, in contrast, contain large amounts of variance at heterodyne periods, the concentration of which increases from south to north. Thomas et al. ${ }^{10}$ attribute the northward increase in heterodyne variance (spectral complexity) to the increasing influence of multiple environmental parameters contributing to the water-isotope signal; records in the south are primarily dominated by summer monsoon variance with simple spectra, composed mostly of primary orbital-scale variance peaks, whereas water-isotope records further north are influenced by both summer- and winter-monsoon variability (i.e., temperature, winter- and summer-monsoon precipitation) resulting in more complex spectra that include heterodyne variance. Our $\delta^{18} \mathrm{O}_{\mathrm{sw}}$ record is consistent with this interpretation, having a combination of primary and heterodyne variance.

The spectral signatures of most EAM proxies are not dominated by 23 -ky variance but, rather, by spectral variance at the 100 - and 41-ky periods more characteristic of late Pleistocene global ice volume and greenhouse gas forcing ${ }^{9-12,26,34}$. The spectral signature of ECS local $\delta^{18} \mathrm{O}_{\text {sw }}$, a record for which the impact of temperature and seawater $\delta^{18} \mathrm{O}$ have been removed, is also well matched to that of $\mathrm{CH}_{4}{ }^{66}, \mathrm{CO}_{2}{ }^{67}$, and the global benthic $\delta^{18} \mathrm{O}$ stack ${ }^{52}$ (Fig. 5a-c). All are dominated by eccentricity-band variance with lesser amounts of obliquity-band variance. With the exception of $\mathrm{CH}_{4}$, all have the least amount of variance in the precession-band. The precession-band variance in $\mathrm{CH}_{4}$ (coequal with obliquity-band variance) has been attributed, in part, to tropical wetland sources ${ }^{66}$. In any case, these records, and their spectral signatures, bear little resemblance to that of direct local or high-latitude summer-insolation forcing (Fig. 5d, e). These findings indicate that the EAM does not respond dominantly and directly to external insolation forcing but, rather, is strongly sensitive to the internal redistribution of this energy, resulting in spectral signatures more similar to those of greenhouse gasses and global ice volume.

In summary, the precession- and millennial-band structure characteristic of YRV $\delta^{18} \mathrm{O}_{\text {cave }}$ is also found offshore in ECS $\delta^{18} \mathrm{O}_{\mathrm{pf}}$. However, after quantitative removal of the local temperature and global seawater $\delta^{18} \mathrm{O}$ signals, the resulting local $\delta^{18} \mathrm{O}_{\text {sw }}$ record (a proxy for rainfall and YRV runoff) no longer matches $\delta^{18} \mathrm{O}_{\text {cave. }}$. Local $\delta^{18} \mathrm{O}_{\mathrm{sw}}$ is dominated by eccentricity- and obliquity-band variance as well as heterodynes thereof, not by precession-band variance as in $\delta^{18} \mathrm{O}_{\text {cave. }}$. The local $\delta^{18} \mathrm{O}_{\text {sw }}$ spectrum, similar to an array of other proxies across the EAM region, is consistent with that of $\mathrm{CO}_{2}, \mathrm{CH}_{4}$, and global ice volume. This indicates that EAM rainfall variability is more sensitive to internal forcing mechanisms related to high-latitude ice sheet and greenhouse gas variability, and less sensitive to direct insolation 
forcing, as is commonly inferred on the basis of the precessiondominated YRV $\delta^{18} \mathrm{O}_{\text {cave }}$ spectrum.

\section{Methods}

Planktonic oxygen and carbon stable isotopes. U1429 was sampled at $5 \mathrm{~cm}$ resolution from 0 to $25 \mathrm{~m}$ below sea floor (mbsf), at 5 or $10 \mathrm{~cm}$ resolution from 25 to $35 \mathrm{mbsf}$, and at 5,10 , or $15 \mathrm{~cm}$ resolution from 35 to $181 \mathrm{mbsf}$. Samples were freeze-dried, wet-sieved at $63 \mu \mathrm{m}$, and dried in an oven at $50{ }^{\circ} \mathrm{C}$. The $>63 \mu \mathrm{m}$ fraction was then sieved into four size fractions, 63-150, 150-250, 250-355, and $>355 \mu \mathrm{m}$. Approximately 50 individual G. ruber (white, sensu stricto) were picked from the $250-355 \mu \mathrm{m}$ size fraction for both stable isotope $\left(\delta^{18} \mathrm{O}, \delta^{13} \mathrm{C}\right)$ and $\mathrm{Mg} / \mathrm{Ca}$ analysis. Approximately 30 and 20 individuals were used for $\mathrm{Mg} / \mathrm{Ca}$ and stable isotope analyses respectively. Samples for stable isotope analyses were sonified in ethanol to remove fine clays, homogenized, and subsampled $\left(\sim 80 \mu \mathrm{g} \mathrm{CaCO}_{3}\right)$ for analysis on the Brown University MAT252 IRMS coupled to a Kiel III carbonate device. Samples were reacted by individual acid addition $\left(99 \% \mathrm{H}_{3} \mathrm{PO}_{4}\right.$ at $\left.70{ }^{\circ} \mathrm{C}\right)$. A total of 2031 G. ruber samples and a total of 314 standards (BYM and Carrara) were analyzed. Repeated analyses of Brown Yule Marble $(n=116,1 \sigma)$ yields -2.27 \pm 0.03 for $\delta^{13} \mathrm{C}$ and $-6.48 \pm 0.07$ for $\delta^{18} \mathrm{O}$. Carrara Marble $(n=198,1 \sigma)$ yield 2.03 \pm 0.03 for $\delta^{13} \mathrm{C}$ and $-1.89 \pm 0.05$ for $\delta^{18} \mathrm{O}$. Replicate analysis of homogenized foraminifera samples $(n=42,1 \sigma)$ yields \pm 0.05 for $\delta^{18} \mathrm{O}$ and \pm 0.03 for $\delta^{13} \mathrm{C}$. All results were calibrated to National Institute of Standards and Technology (Gaithersburg, Maryland) carbonate isotope standard NBS 19 and are reported as \%o VPDB.

Benthic oxygen and carbon stable isotopes. U1429 was sampled at 10, 15, 25, or $30 \mathrm{~cm}$. Samples were dried in an oven at $40^{\circ} \mathrm{C}$, wet-sieved at $63 \mu \mathrm{m}$, and dried in an oven at $40^{\circ} \mathrm{C}$. Three to ten well-preserved tests (Uvigerina spp, C. wuellerstorfi depending on availability) were broken into large fragments, cleaned in alcohol in an ultrasonic bath, then dried at $40^{\circ} \mathrm{C}$. In a few samples, where foraminiferal density was low, only 1-2 specimens were analyzed. Measurements were made with the Finnigan MAT 251 mass spectrometer at the Leibniz Laboratory, Kiel University. The instrument is coupled on-line to a Carbo-Kiel Device (Type I). Samples were reacted by individual acid addition $\left(99 \% \mathrm{H}_{3} \mathrm{PO}_{4}\right.$ at $\left.73{ }^{\circ} \mathrm{C}\right)$. Standard external error is better than $\pm 0.07 \%$ and $\pm 0.05 \%$ for $\delta^{18} \mathrm{O}$ and $\delta^{13} \mathrm{C}$, respectively. Replicate measurements on $\sim 5 \%$ of samples indicate mean reproducibility better than $\pm 0.11 \%$ and $\pm 0.13 \%$ or for $\delta^{18} \mathrm{O}$ and $\delta^{13} \mathrm{C}$, respectively. Results were calibrated using the National Institute of Standards and Technology (Gaithersburg, Maryland) carbonate isotope standard NBS 19 along with three internal standards, and are reported on the PeeDee belemnite (VPDB) scale.

SST and $\boldsymbol{\delta}^{\mathbf{1 8}} \mathbf{O}_{\text {sw }}$ reconstruction. $\mathrm{Mg} / \mathrm{Ca}$ analysis of G. ruber sensu stricto (ss) was carried out for U1429 at intervals of approximately 10,15, 25, or $30 \mathrm{~cm}$, using splits of the same G. ruber fraction used to measure planktonic $\delta^{18} \mathrm{O}$. Prior to measurement, foraminiferal tests were cleaned following the reductive approach, modified from Boyle and Keigwin ${ }^{68}$, as detailed in refs. ${ }^{41}$ and ${ }^{42}$. The metal/Ca ratios of most of samples were determined with a Thermo Scientific ELEMENT $\mathrm{XR}$, a double focusing sector field inductively coupled plasma mass spectrometer (ICP-MS) at the Mutsu Institute for Oceanography (MIO); 87 samples in MIS 5 were determined with an ELEMENT 2 at the University of Toyama ${ }^{41}$. The elements ${ }^{24} \mathrm{Mg}$ and ${ }^{44} \mathrm{Ca}$, measured in a middle resolution mode, were used to determine $\mathrm{Mg} / \mathrm{Ca}$ for the samples analyzed at the MIO. The precision of the measurement was checked by replicate measurement (every five to six samples) of working standards produced at MIO from high purity standards $(1000 \pm 3 \mathrm{mg} / \mathrm{L})$ SPEX Claritas PPT. Relative standard deviation (RSD) of the working standards was $<2.6 \%$ at MIO. The $\mathrm{CaCO}_{3}$ reference material CRM was used as a working standard and RSD of its replicate analyses was $1.1 \%$ at the University of Toyama. The accuracy of $\mathrm{Mg} / \mathrm{Ca}$ ratios were confirmed by analyses of a $\mathrm{CaCO}_{3}$ reference standard, coral Porites standard material JCp-1, whose $\mathrm{Mg} / \mathrm{Ca}$ values was internationally determined $\left(4.199 \pm 0.065 \mathrm{mmol} / \mathrm{mol}^{69}\right.$,). The measured $\mathrm{Mg} / \mathrm{Ca}$ of JCp-1 was $4.161 \pm 0.064(1 \sigma, N=24) \mathrm{mmol} / \mathrm{mol}$ at $\mathrm{MIO}$ and $4.148 \pm 0.055(1 \sigma, N=11)$ $\mathrm{mmol} / \mathrm{mol}$ at the University of Toyama. Based on the difference of $\mathrm{Mg} / \mathrm{Ca}$ between two laboratories, $0.0131 \mathrm{mmol} / \mathrm{mol}$ was added for the $\mathrm{Mg} / \mathrm{Ca}$ data measured at the University of Toyama. In addition to $\mathrm{Mg} / \mathrm{Ca}, \mathrm{Mn} / \mathrm{Ca}$ were measured to monitor the contamination by diagenetic coating. $\mathrm{Mn} / \mathrm{Ca}$ of $99 \%$ of the samples were less than $0.5 \mathrm{mmol} / \mathrm{mol}$. As there was no positive relationship between $\mathrm{Mg} / \mathrm{Ca}$ and $\mathrm{Mn} /$ $\mathrm{Ca}(>0.5 \mathrm{mmol} / \mathrm{mol})$, we did not eliminate high $\mathrm{Mn} / \mathrm{Ca}$ samples.

Sixteen samples were repicked and rerun for duplication test for $\mathrm{Mg} / \mathrm{Ca}$ in MIO. The average of the difference of $\mathrm{Mg} / \mathrm{Ca}$ between duplicates was $0.086 \pm 0.149(1 \sigma)$ $\mathrm{mmol} / \mathrm{mol}$, which was equivalent to $0.48 \pm 0.36^{\circ} \mathrm{C}$. The effect of preferential removal of $\mathrm{Mg}^{2+}$ from foraminiferal calcite on $\mathrm{Mg} / \mathrm{Ca}$ values due to dissolution on the sea floor (e.g., ref. ${ }^{70}$ and references therein) is likely negligible because the water depth of the core site $(732 \mathrm{~m})$ is well above the modern lysocline $(\sim 1600 \mathrm{~m})$ in the ECS and over $800 \mathrm{~m}$ above the depth at which dissolution impacts the $\mathrm{Mg} / \mathrm{Ca}$ temperature estimation in this region ${ }^{41}$.

Seawater $\delta^{18} \mathrm{O}$ is derived using Paleo-Seawater Uncertainty Solver (PSU Solver ${ }^{71}$ ) No regional $\mathrm{Mg} / \mathrm{Ca}$ calibration exists for the East China Sea. We employ the $\mathrm{Mg} / \mathrm{Ca}$ calibration of Tierney et al. ${ }^{72}$ that utilizes all available culture data in a multivariate calibration that accounts for both salinity and temperature. This calibration has an exponential slope of $8.4 \pm 1.5 \% /{ }^{\circ} \mathrm{C}$, consistent with that previously used in the East China Sea ${ }^{41}$ which has an exponential slope of $8.9 \% /{ }^{\circ} \mathrm{C}$ but does not account for salinity. We utilize the seawater $\delta^{18} \mathrm{O}$-temperature relationship (low light) of Bemis et al. ${ }^{73}$, the ECS G. ruber core top seawater $\delta^{18} \mathrm{O}$ salinity relationship of Horikawa et al. ${ }^{41}$, and the global sea level curve of Waelbroeck et al. ${ }^{74}$. Instead of using the Waelbroeck curve directly, the U1429 benthic $\delta^{18} \mathrm{O}$ record was scaled to match the Waelbroeck curve such that the age model and high-resolution sampling at U1429 remains intact. Scaling is accomplished by normalizing the U1429 benthic $\delta^{18} \mathrm{O}$ record followed by multiplication of each sample by 0.313 (the standard deviation of the Waelbroeck curve) and addition of 0.364 to align the core top to a value of $0.27 \%$. Propagated uncertainty $(1 \sigma)$ in $\delta^{18} \mathrm{O}_{\mathrm{sw}}$ is assessed using the following error estimates on the underlying parameters $\left(\delta{ }^{18} \mathrm{O}_{\mathrm{pf}} \pm 0.1 \% \mathrm{mg} / \mathrm{Ca} \pm 0.2 \mathrm{mmol} / \mathrm{mol}\right.$, and age $\left.\pm 2 \mathrm{ky}\right)$. The resulting time series and spectra are shown in Supplementary Figure 8a.

We assess sensitivity to the temperature term and calibration approach by comparing our Seawater $\delta^{18} \mathrm{O}$ result to that derived using SST from Eq. (3) of Gray et $\mathrm{al}^{75}$. Equation (3) from Grey et al. expresses $\mathrm{Mg} / \mathrm{Ca}$ as a function of temperature, salinity, and $\mathrm{pH}$ using calibration data from 440 globally distributed plankton tow and sediment trap samples. The temperature sensitivity $\left(6 \pm 0.8 \% /{ }^{\circ} \mathrm{C}\right)$ is considerably smaller than that in the Tierney equation $\left(8.4 \pm 1.5 \% /{ }^{\circ} \mathrm{C}\right)$. Sediment trap and tow data use natural, open ocean conditions relative to laboratorycontrolled conditions. $\mathrm{pH}$ is derived using a simple linear regression of $\mathrm{G}$. ruber $\delta^{18} \mathrm{O}$ vs. $\mathrm{pH}$ from the ODP Site 999A data presented in Fig 9a of Foster et al. ${ }^{76}$ :

$$
\mathrm{pH}=0.045^{*} \delta^{18} \mathrm{O}+8.25\left(n=29, r^{2}=0.76, p>0.0001\right)
$$

Equation 1, applied to U1429 G. ruber $\delta^{18} \mathrm{O}$, yields a first-order estimate of surface water $\mathrm{pH}$ for the past 400 kyrs, presuming the calibration from 999A (Caribbean Sea) is appropriate for U1429 (East China Sea). PSU solver is used to derive local seawater $\delta^{18} \mathrm{O}$ for comparison with results from the Tierney 2015 calibration equation. The result is shown in Supplementary Fig. 8b; despite the differences in the temperature coefficients and underlying calibration approaches, both results are dominated by $100-\mathrm{kyr}$ variability with very little precession-scale variance.

Quantitative reconstruction of salinity is not attempted, given the unconstrained nature of the $\delta^{18} \mathrm{O}_{\mathrm{sw}}$ salinity relationship over time $23,54,77$. No reliable information is available on the potentially variable slope of the $\delta^{18} \mathrm{O}_{\mathrm{sw}^{-}}$ salinity relationship in the ECS over the past 400,000 years. Such evaluation awaits reliable, time-dependent isotope-enabled simulations with realistic boundary conditions ${ }^{23}$.

SST was also reconstructed using the $\mathrm{UK}^{\prime}{ }_{37}$ approach. Bulk sediment samples $(3 \mathrm{~g})$ were taken from the core at $10 \mathrm{~cm}$ intervals for alkenone analysis. Long-chain alkenones were extracted from freeze-dried sediment samples. Organic compounds were extracted using an accelerated solvent extractor (ASE 200, Dionex) with a solvent mixture $\left(\mathrm{CH}_{2} \mathrm{Cl}_{2}: \mathrm{CH}_{3} \mathrm{OH}, 99: 1 \mathrm{v} / \mathrm{v}\right)$ at high temperature $\left(100^{\circ} \mathrm{C}\right)$ and pressure $(1500 \mathrm{psi})$. The extracts were cleaned by elution $\left(3 \times 500 \mu \mathrm{l} \mathrm{CH}_{2} \mathrm{Cl}_{2}\right)$ through a silica cartridge. Saponification was performed at $80^{\circ} \mathrm{C}$ for $2 \mathrm{~h}$ with $300 \mu \mathrm{l}$ of $0.1 \mathrm{M} \mathrm{KOH}$ in $90 / 10 \mathrm{CH}_{3} \mathrm{OH} / \mathrm{H}_{2} \mathrm{O}$. The neutral fraction, containing the alkenones, was obtained by partitioning into hexane. After being concentrated under $\mathrm{N}_{2}$, the final extract was analyzed using a gas chromatograph (Agilent $7890 \mathrm{~A}$ ) equipped with a flame ionization detector and a DB-1 column $(60 \mathrm{~m} \times 0.32 \mathrm{~mm}$ i.d. $)$. Temperatures were calculated using the alkenone unsaturation index $\left(\mathrm{U}^{\prime}{ }_{37}\right)$ and the calibration equation of Prahl et al. ${ }^{78}$ $\left(\mathrm{UK}^{\prime}{ }_{37}=0.034 \mathrm{~T}+0.039\right.$; Supplementary Fig. 7$)$. Reproducibility of alkenone temperatures for replicate samples of a homogeneous marine sediment lab standard run during the project is better than $\pm 0.2^{\circ} \mathrm{C}(n=124,2 \sigma)$. Duplicate analyses from $\mathrm{U} 1429$ is $\pm 0.4^{\circ} \mathrm{C}(n=312 \sigma)$. Supplementary Fig. 8c shows local seawater $\delta^{18} \mathrm{O}$ reconstructed using the U1429 $\mathrm{U}^{\mathrm{K}}{ }_{37}$ SST record instead of the $\mathrm{U} 1429 \mathrm{Mg} / \mathrm{Ca}$ record; the result is again a record dominated by $100-\mathrm{kyr}$ variance with very little 23-kyr variance, as expected on the basis of Supplemental Fig. 7 which shows the same precession-band variance is as in $\mathrm{Mg} / \mathrm{Ca}$-derived SST, but greater 100-kyr variance.

U1429 age model. A traditional marine chronostratigraphy (benthic age model) was established by mapping the U1429 benthic $\delta^{18} \mathrm{O}$ to the global benthic stack ${ }^{52}$ over the past $400 \mathrm{ky}$ (Supplementary Table 1). This was accomplished by correlation of structure in the two records using the Linage function in Analyseries ${ }^{79}$. Cross-spectral analysis documents high coherence $(>0.95 \mathrm{CI})$ and near-zero phase at the eccentricity $(-2 \pm 0.7 \mathrm{ky})$, obliquity $(0.5 \pm 0.5 \mathrm{ky})$ and precession bands $(-0.7 \pm 0.3 \mathrm{ky}$ ) (Supplementary Fig. 4 ). The 100 - and $41-\mathrm{ky}$ variance was then removed from planktonic $\delta^{18} \mathrm{O}$ (benthic age model) by notch filtering the 100 - and 41 -ky variance (Methods). The result was then mapped to the Cheng et al. ${ }^{15}$ composite cave $\delta^{18} \mathrm{O}$ record using the Analyseries Linage function (Supplementary Table 1). This fine-tuning of the U1429 benthic age model (cave-based age model) is justified on the basis that benthic $\delta^{18} \mathrm{O}$ on the two age models are highly coherent $(>0.99 \mathrm{CI})$ with near-zero phase at the eccentricity $(0.08 \pm 0.35 \mathrm{ky})$, obliquity $(-0.23 \pm 0.29 \mathrm{ky})$ and precession $(0.23 \pm 0.17 \mathrm{ky})$ bands. 
CCSM3 simulations. Paleoclimate simulations were performed using the National Center for Atmospheric Research (NCAR) Community Climate System Model (CCSM) version $3.5^{56,80}$ in the fully coupled configuration (active atmosphere, ocean, land, and sea ice). The ocean model has a zonal resolution that varies from $340 \mathrm{~km}$ at the equator to $40 \mathrm{~km}$ around Greenland and $350 \mathrm{~km}$ in the Northern Pacific. This spatially varying resolution is achieved by placing the north pole of the grid over Greenland and reflects the different relevant length scales of the two processes that are important in maintaining a stable global climate; deep convection around Greenland and in the Arctic as well as ocean heat uptake at the equator. In the vertical there are 25 depth levels; the uppermost layer has a thickness of $8 \mathrm{~m}$ and the deepest layer has a thickness of $500 \mathrm{~m}$. This and the atmospheric, land, and sea-ice models operate under the T31_3_3 setup ${ }^{80}$, which have been developed specifically for long paleoclimate and biogeochemistry applications.

Insolation was calculated using orbital parameters from Berger and Loutre ${ }^{13}$ Atmospheric $\mathrm{CO}_{2}$ and $\mathrm{CH}_{4}$ were prescribed $\left(\mathrm{CO}_{2}\right.$, IGBP PAGES/WDCA contribution series number: $2008-055^{81} ; \mathrm{CH}_{4}$, IGBP PAGES/WDCA contribution series number: $2008-054^{66}$.) Continental ice sheets and sea level (i.e., land-ocean boundaries) were prescribed by scaling the ICE-5G ice distribution for the LGM to present ${ }^{82}$ to the marine benthic $\delta^{18} \mathrm{O}$ record ${ }^{52}$ and saving these parameters as boundary conditions for the model. At the end of each year of the simulation, the orbital parameters and the atmospheric greenhouse gases were advanced by 100 years. When the model boundary conditions changed (e.g., land-ocean boundaries changing due to sea level rise or fall equivalent to $40 \mathrm{~m}$ ), all the components of the model were reconfigured manually and the model was restarted using the previous year as the initial conditions. This acceleration technique, similar to those used in other paleoclimatic modeling studies $2,83-85$, enables us to gain insight into the temporal evolution of the climate system given restricted computer resources. Several studies have shown that acceleration factors of 10 and 100 produced similar results ${ }^{84}$. Jackson and Broccoli ${ }^{83}$, for example, used an acceleration factor of 30 in a simulation of the past 165,000 years. The upper ocean and the atmosphere reach quasi-equilibrium in this acceleration approach ${ }^{2}$. In our acceleration approach, the change in insolation forcing is small $(<0.5 \mathrm{~W} / \mathrm{m})$ from year to year at all latitudes in the shortest orbital cycle (precession) ${ }^{58}$.

The experiment consisted of three separate simulations, beginning with an insolation only simulation, followed by addition of greenhouse gasses, followed by addition of ice-volume and sea level (Fox-Kemper et al., manuscript in preparation). Successively adding boundary conditions is a useful method for understanding the sensitivity of the model response to these forcing mechanisms. Results in this manuscript are from the simulation using the full set of boundary conditions. Model precipitation data were averaged for the regions depicted in Fig. 1. Monthly maximum, minimum, and annual average model output were used in comparison with proxy data. Use of monthly maximum and minimum values (as opposed JJA, DFJ) accounts for the fact that the timing of maximum insolation, in the northern hemisphere (for example), can occur in May, June, or July depending on the orbital configuration and is thus, not tied to any single orbital configuration (e.g., June 21 Perihelion).

Currently, accelerated models assume that Earth's orbit is fixed, meaning that changes in the length and strength of Earth's seasons due to changes in Earth's orbital parameters are not accounted for in the definition of the calendar upon which monthly values are computed. While this is not a major issue for Holocenescale studies ${ }^{84,86}$, it becomes important for orbital-scale simulations $s^{2,57,58,83}$. Therefore, it is important to identify and correct for this calendar effect if one wishes to accurately relate paleoclimate model results to real-world paleoclimate records. The calendar problem was corrected for (Nelson A.D. et al., manuscript in preparation) by following the methodology of other works ${ }^{57,87,88}$.

Time series analysis. Cross-spectral analyses were performed with the Blackman-Tukey approach using Analyseries software ${ }^{79}$. All spectra employed a Bartlett window and a $30 \%(n / 3)$ lag where $\mathrm{n}$ is the number of series data points. For model-proxy comparisons, the bandwidth is 0.0167 , non-zero coherence is $>0.3844$, and the error estimation on the power spectrum is 0.6255 . For proxy-proxy comparisons, the bandwidth is 0.0127 , non-zero coherence is $>0.3844$, and the error estimation on the power spectrum is 0.6255 .

Notching (removing) the 100-kyr (eccentricity) and 41-kyr (obliquity) variance was accomplished by filtering (Gaussian) at a central frequency of 0.01 and a bandwidth of 0.005 for eccentricity and a central frequency of 0.0245 and a bandwidth of 0.0035 for obliquity.

Individual linear spectra were calculated using the Analyseries periodogram function and a Bartlett window. The periodogram produces an unsmoothed spectrum (equivalent to the Blackman-Tukey with a $100 \% \mathrm{lag}$ ). It is useful in that it does not smooth away side lobes that may be present due to, for example, time scale inaccuracies. Since Analyseries does not have a means of assessing confidence, the Periodogram tool on the NASA Exoplanet Archive site (http://

exoplanetarchive.ipac.caltech.edu/cgi-bin/Pgram/nph-pgram) was used to assess orbital-scale spectral peaks discussed in the manuscript for frequencies $<0.05$ (periods greater than $20 \mathrm{ky}$ ) using the Lomb-Scargle algorithm ${ }^{89}$. Peaks discussed in the manuscript at frequencies $<0.05$ labeled with * do not meet the $p=0.05$ threshold level for probability of chance occurrence.
Data availability. All data necessary to assess the validity of this research are presented in the paper and Supplementary Materials. The paleoclimate proxy data are archived at NOAA's National Centers for Environmental Information (NCEI).

Received: 24 October 2017 Accepted: 26 July 2018

Published online: 22 August 2018

\section{References}

1. Overpeck, J. T. \& Cole, J. E. Abrupt change in Earth's climate system. Annu. Rev. Environ. Resour. 31, 1-31 (2006).

2. Timmermann, A., Lorenz, S. J., An, S. I., Clement, A. \& Xie, S. P. The effect of orbital forcing on the mean climate and variability of the tropical Pacific. J. Clim. 20, 4147-4159 (2007).

3. Berger, A. L. Long-term variations of caloric insolation resulting from the Earth's orbital elements. Quat. Res. 9, 139-167 (1978).

4. Laskar, J., Jouzel, F. \& Boudin, F. Orbital, precessional, and insolation quantities for the Earth from $-20 \mathrm{Myr}$ to $+10 \mathrm{Myr}$. Astron. Astrophys. 270, 522-533 (1993).

5. Cheng, H., Sinha, A., Wang, X., Cruz, F. \& Edwards, R. L. The Global Paleomonsoon as seen through speleothem records from Asia and the Americas. Clim. Dyn. 39, 1045-1062 (2012).

6. Wang, P. et al. Evolution and variability of the Asian monsoon system: state of the art and outstanding issues. Quat. Sci. Rev. 24, 595-629 (2005).

7. An, Z. et al. in Late Cenozoic Climate Change in Asia: Loess, Monsoon and Monsoon-arid Environment Evolution (ed Zhisheng, A.) 491-581 (Springer Netherlands, Dordrecht, 2014).

8. Maher, B. A. Holocene variability of the East Asian summer monsoon from Chinese cave records: a re-assessment. Holocene 18, 861-866 (2008).

9. Maher, B. A. Palaeoclimatic records of the loess/palaeosol sequences of the Chinese Loess Plateau. Quat. Sci. Rev. 154, 23-84 (2016).

10. Thomas, E. K. et al. Heterodynes dominate precipitation isotopes in the East Asian monsoon region, reflecting interaction of multiple climate factors. Earth Planet. Sci. Lett. 455, 196-206 (2016).

11. Sun, Y. et al. Astronomical and glacial forcing of East Asian summer monsoon variability. Quat. Sci. Rev. 115, 132-142 (2015).

12. Beck, J. W. et al. A 550,000-year record of East Asian monsoon rainfall from ${ }^{10} \mathrm{Be}$ in loess. Science 360, 877 (2018).

13. Berger, A. \& Loutre, M. F. Insolation values for the climate of the last 10 million years. Quat. Sci. Rev. 10, 297-317 (1991).

14. Wang, Y. et al. Millennial- and orbital-scale changes in the East Asian monsoon over the past 224,000 years. Nature 451, https://doi.org/10.1038/ nature06692 (2008).

15. Cheng, H. et al. The Asian monsoon over the past 640,000 years and ice age terminations. Nature 534, 640-646 (2016).

16. Cheng, H. et al. Ice age terminations. Science 326, 248-252 (2009).

17. Orland, I. J. et al. Direct measurements of deglacial monsoon strength in a Chinese stalagmite. Geology 43, 555-558 (2015).

18. Goldsmith, Y. et al. Northward extent of East Asian monsoon covaries with intensity on orbital and millennial timescales. Proc. Natl Acad. Sci. USA 114, 1817-1821 (2017).

19. Liu, J., Chen, S., Chen, J., Zhang, Z. \& Chen, F. Chinese cave $\delta^{18}$ O records do not represent northern East Asian summer monsoon rainfall. Proc. Natl Acad. Sci. USA 114, E2987-E2988 (2017).

20. Dayem, K. E., Molnar, P., Battisti, D. S. \& Roe, G. H. Lessons learned from oxygen isotopes in modern precipitation applied to interpretation of speleothem records of paleoclimate from eastern Asia. Earth Planet. Sci. Lett. 295, 219-230 (2010).

21. Pausata, F. S. R., Battisti, D. S., Nisancioglu, K. H. \& Bitz, C. M. Chinese stalagmite $\delta^{18} \mathrm{O}$ controlled by changes in the Indian monsoon during a simulated Heinrich event. Nat. Geosci. 4, 474-480 (2011).

22. Lee, J.-E. et al. Asian monsoon hydrometeorology from TES and SCIAMACHY water vapor isotope measurements and LMDZ simulations: implications for speleothem climate record interpretation. J. Geophys. Res. Atmos. 117, D15112 (2012).

23. Caley, T. \& Roche, D. M. Modeling water isotopologues during the last glacial: implications for quantitative paleosalinity reconstruction. Paleoceanography 30, 739-750 (2015).

24. Liu, Z. et al. Chinese cave records and the East Asia Summer Monsoon. Quat. Sci. Rev. 83, 115-128 (2014).

25. Caley, T., Roche, D. M. \& Renssen, H. Orbital Asian summer monsoon dynamics revealed using an isotope-enabled global climate model. Nat. Commun. 5, 5371 (2014).

26. Maher, B. A. \& Thompson, R. Oxygen isotopes from Chinese caves: records not of monsoon rainfall but of circulation regime. J. Quat. Sci. 27, 615-624 (2012). 
27. Clemens, S. C., Prell, W. L. \& Sun, Y. Orbital-scale timing and mechanisms driving Late Pleistocene Indo-Asian summer monsoons: reinterpreting cave speleothem $\delta^{18}$ O. Paleoceanography 25, PA4207 (2010).

28. Chiang, J. C. H. et al. Role of seasonal transitions and westerly jets in East Asian paleoclimate. Quat. Sci. Rev. 108, 111-129 (2015).

29. Kong, W., Swenson, L. M. \& Chiang, J. C. H. Seasonal transitions and the westerly jet in the Holocene East Asian summer monsoon. J. Clim. 30, 3343-3365 (2017).

30. James, E. W., Banner, J. L. \& Hardt, B. A global model for cave ventilation and seasonal bias in speleothem paleoclimate records. Geochem. Geophys. Geosystems 16, 1044-1051 (2015).

31. Lachniet, M. S. Climatic and environmental controls on speleothem oxygenisotope values. Quat. Sci. Rev. 28, 412-432 (2009).

32. Duan, W. et al. The transfer of seasonal isotopic variability between precipitation and drip water at eight caves in the monsoon regions of China. Geochim. Cosmochim. Acta 183, 250-266 (2016).

33. Battisti, D. S., Ding, Q. \& Roe, G. H. Coherent pan-Asian climatic and isotopic response to orbital forcing of tropical insolation. J. Geophys. Res. Atmos. 119, 11,997-912,020 (2014).

34. Thomas, E. K. et al. Temperature and leaf wax $\delta^{2} \mathrm{H}$ records demonstrate seasonal and regional controls on Asian monsoon proxies. Geology 42, 1075-1078 (2014).

35. Tada, R., Murray, R. W., Alvarez Zarikian, C. A. \& Expedition 346 Scientists (2015). Sites U1428 and U1429. In Proc. IODP, 346 Vol. 346, Integrated Ocean Drilling Program, College Station, TX.

36. Chu, P., Yuchun, C. \& Kuninaka, A. Seasonal variability of the Yellow Sea/East China Sea surface fluxes and thermohaline structure. Adv. Atmos. Sci. 22, 1-20 (2005).

37. Johnson, D. R. \& Boyer, T. P. East Asian Seas Regional Climatology (Version 2.0). NOAA National Center for Environmental Information, USA. https:// doi.org/10.7289/V5MP5171 (2015).

38. Delcroix, T. \& Murtugudde, R. Sea surface salinity changes in the East China Sea during 1997-2001: Influence of the Yangtze River. J. Geophys. Res. Oceans 107, 9-11 (2002).

39. Kim, H.-C. et al. Distribution of Changjiang Diluted Water detected by satellite chlorophyll-a and its interannual variation during 1998-2007. J. Oceanogr. 65, 129-135 (2009).

40. Zhang, J., Letolle, R., Martin, J. M., Jusserand, C. \& Mouchel, J. M. Stable oxygen isotope distribution in the Huanghe (Yellow River) and the Changjiang (Yangtze River) estuarine systems. Cont. Shelf Res. 10, 369-384 (1990).

41. Horikawa, K., Kodaira, T., Zhang, J. \& Murayama, M. $\delta^{18}$ Osw estimate for Globigerinoides ruber from core-top sediments in the East China Sea. Progress. Earth Planet. Sci. 2, 1-20 (2015).

42. Kubota, Y., Tada, R. \& Kimoto, K. Changes in East Asian summer monsoon precipitation during the Holocene deduced from a freshwater flux reconstruction of the Changjiang (Yangtze River) based on the oxygen isotope mass balance in the northern East China Sea. Clim Past 11, 265-281 (2015).

43. Wang, Y. J. et al. The Holocene Asian monsoon: links to solar changes and North Atlantic climate. Science 308, 854-857 (2005).

44. Sun, B. \& Wang, H. Analysis of the major atmospheric moisture sources affecting three sub-regions of East China. Int. J. Climatol. 35, 2243-2257 (2014).

45. Müller, B., Berg, M., Pernet-Coudrier, B., Qi, W. \& Liu, H. The geochemistry of the Yangtze River: Seasonality of concentrations and temporal trends of chemical loads. Global. Biogeochem. Cycles 26, GB2028 (2012).

46. Liu, J., Song, X., Yuan, G. \& Sun, X. Stable isotopic compositions of precipitation in China. Tellus B 66, 22567 (2014).

47. Chen, X., Wang, X. \& Guo, J. Seasonal variability of the sea surface salinity in the East China Sea during 1990-2002. J. Geophys. Res. Oceans 111, C05008 (2006).

48. Xu, X., Yamasaki, M., Oda, M. \& Honda, M. C. Comparison of seasonal flux variations of planktonic foraminifera in sediment traps on both sides of the Ryukyu Islands, Japan. Mar. Micropaleontol. 58, 45-55 (2005).

49. Zhang, L. et al. Reevaluation of mixing among multiple water masses in the shelf: An example from the East China Sea. Cont. Shelf Res. 27, 1969-1979 (2007).

50. Inoue, $\mathrm{M}$. et al. Spatial variations of ${ }^{226} \mathrm{Ra},{ }^{228} \mathrm{Ra}$, and ${ }^{228} \mathrm{Th}$ activities in seawater from the eastern East China Sea. Geochem. J 46, 429-441 (2012).

51. Lee, K. E. et al. Stability of the Kuroshio path with respect to glacial sea level lowering. Geophys. Res. Lett. 40, 392-396 (2013).

52. Lisiecki, L. E. \& Raymo, M. E. A Pliocene-Pleistocene stack of 57 globally distributed benthic $\delta^{18} \mathrm{O}$ records. Paleoceanography 20, https://doi.org/ 10.1029/2004PA001071 (2005).

53. Kubota, Y. et al. Variations of East Asian summer monsoon since the last deglaciation based on $\mathrm{Mg} / \mathrm{Ca}$ and oxygen isotope of planktic foraminifera in the northern East China Sea. Paleoceanography 25, PA4205 (2010).
54. Holloway, M. D., Sime, L. C., Singarayer, J. S., Tindall, J. C. \& Valdes, P. J. Reconstructing paleosalinity from $\delta^{18} \mathrm{O}$ : coupled model simulations of the last Glacial maximum, last Interglacial and late Holocene. Quat. Sci. Rev. 131, 350-364 (2016).

55. Liu, Z. et al. Clay mineral distribution in surface sediments of the northeastern South China Sea and surrounding fluvial drainage basins: source and transport. Mar. Geol. 277, 48-60 (2010).

56. Collins, W. D. et al. The community climate system model version 3 (CCSM3). J. Clim. 19, 2122-2143 (2006).

57. Chen, G.-S., Liu, Z., Clemens, S., Prell, W. L. \& Liu, X. Modeling the timedependent response of the Asian summer monsoon to obliquity forcing in a coupled GCM: a PHASEMAP sensitivity experiment. Clim. Dyn. https://doi. org/10.1002/2016GL071882 (2010).

58. Kutzbach, J. E., Liu, X., Liu, Z. \& Chen, G. Simulation of the evolutionary response of global summer monsoons to orbital forcing over the past 280,000 years. Clim. Dyn. 30, 567-579 (2008).

59. Thomas, E. K. et al. Midlatitude land surface temperature impacts the timing and structure of glacial maxima. Geophys. Res. Lett. 44, 984-992 (2017).

60. Partin, J. W., Cobb, K. M., Adkins, J. F., Clark, B. \& Fernandez, D. P. Millennial-scale trends in west Pacific warm pool hydrology since the last Glacial Maximum. Nature 449, 452-455 (2007).

61. Yoo, D.-G. et al. Seismic stratigraphy and depositional history of late Quaternary deposits in a tide-dominated setting: an example from the eastern Yellow Sea. Mar. Pet. Geol. 73, 212-227 (2016)

62. Maher, B. A. The magnetic properties of Quaternary aeolian dusts and sediments, and their palaeoclimatic significance. Aeolian Res. 3, 87-144 (2011).

63. Braconnot, P. et al. Results of PMIP2 coupled simulations of the MidHolocene and Last glacial maximum-Part 1: experiments and large-scale features. Clim. Past. 3, 261-277 (2007).

64. Yanase, W. \& Abe-Ouchi, A. The LGM surface climate and atmospheric circulation over East Asia and the North Pacific in the PMIP2 coupled model simulations. Clim. Past. 3, 439-451 (2007).

65. Tian, Z. \& Jiang, D. Revisiting last glacial maximum climate over China and East Asian monsoon using PMIP3 simulations. Palaeogeogr. Palaeoclimatol. Palaeoecol. 453, 115-126 (2016).

66. Loulergue, L. et al. Orbital and millennial-scale features of atmospheric $\mathrm{CH}_{4}$ over the past 800,000 years. Nature 453, 383-386 (2008).

67. Petit, J. R. et al. Climate and Atmospheric History of the Past 420,000 years from the Vostok Ice Core, Antarctica. Nature 399, 429-436 (1999).

68. Boyle, E. A. \& Keigwin, L. D. Comparison of Atlantic and Pacific paleochemical records for the last 215,000 years: changes in deep ocean circulation and chemical inventories. Earth Planet. Sci. Lett. 76, 135-150 (1985).

69. Hathorne, E. C. et al. Interlaboratory study for coral Sr/Ca and other element/ Ca ratio measurements. Geochem. Geophys. Geosyst. 14, 3730-3750 (2013)

70. Dekens, P. S., Lea, D. W., Pak, D. K. \& Spero, H. J. Core top calibration of Mg/ $\mathrm{Ca}$ in tropical foraminifera: refining paleotemperature estimation. Geochem. Geophys. Geosyst. 3, 1-29 (2002).

71. Thirumalai, K., Quinn, T. M. \& Marino, G. Constraining past seawater $\delta^{18} \mathrm{O}$ and temperature records developed from foraminiferal geochemistry. Paleoceanography 31, 1409-1422 (2016).

72. Tierney, J. E., Pausata, F. S. R. \& deMenocal, P. Deglacial Indian monsoon failure and North Atlantic stadials linked by Indian Ocean surface cooling Nat. Geosci. 9, 46 (2015).

73. Bemis, B. E., Spero, H. J., Bijma, J. \& Lea, D. W. Reevaluation of the oxygen isotopic composition of planktonic foraminifera: experimental results and revised paleotemperature equations. Paleoceanography 13, 150-161 (1998).

74. Waelbroeck, C. et al. Sea-level and deep water temperature changes derived from benthic foraminifera isotopic records. Quat. Sci. Rev. 21, 295-305 (2002).

75. Gray, W. R. et al. The effects of temperature, salinity, and the carbonate system on $\mathrm{Mg} / \mathrm{Ca}$ in Globigerinoides ruber (white): a global sediment trap calibration. Earth Planet. Sci. Lett. 482, 607-620 (2018).

76. Foster, G. L. Seawater $\mathrm{pH}, \mathrm{pCO}_{2}$ and $\left[\mathrm{CO}^{2-}{ }_{3}\right]$ variations in the Caribbean Sea over the last $130 \mathrm{kyr}$ : a boron isotope and B/Ca study of planktic foraminifera. Earth Planet. Sci. Lett. 271, 254-266 (2008).

77. Wang, P. et al. Monsoon influence on planktic $\delta^{18} \mathrm{O}$ records from the South China Sea. Quat. Sci. Rev. 142, 26-39 (2016).

78. Prahl, F. G., Muehlhausen, L. A. \& Zahnle, D. L. Further evaluation of long chain alkenones as indicators of paleoceanographic conditions. Geochim. Cosmochim. Acta 52, 2303-2310 (1988).

79. Paillard, D., Labeyrie, L., Yiou, P. Macintosh Program performs time-series analysis Eos Trans. AGU. 77, 379 (1996).

80. Yeager, S. G., Shields, C. A., Large, W. G. \& Hack, J. J. The low-resolution CCSM3. J. Clim. 19, 2545-2566 (2006).

81. Luthi, D. et al. High-resolution carbon dioxide concentration record 650,000800,000 years before present. Nature 453, 379-382 (2008). 
82. Peltier, W. R. Global glacial isostasy and the surface of the ice-age Earth: The ICE5G (VM2) model and GRACE. Ann. Rev. Earth Planet Sci. 32, 111-149 (2004).

83. Jackson, C. S. \& Broccoli, A. J. Orbital forcing of Arctic climate: mechanisms of climate response and implications for continental glaciation. Clim. Dyn. 21, 539-557 (2003).

84. Lorenz, S. J. \& Lohmann, G. Accelerated technique for Milankovitch-type forcing in a coupled atmosphere-ocean circulation model: method and application for the Holocene. Clim. Dynamcis 23, 727-743 (2004).

85. Liu, Z. Y., Wang, Y., Gallimore, R., Notaro, M. \& Prentice, I. C. On the cause of abrupt vegetation collapse in North Africa during the Holocene: climate variability vs. vegetation feedback. Geophys. Res. Lett. 33, L22709 (2006).

86. Liu, Z. et al. Transient simulation of last deglaciation with a new mechanism for Bolling-Allerod warming. Science 325, 310-314 (2009).

87. Pollard, D. \& Reusch, D. B. A calendar conversion method for monthly mean paleoclimate model output with orbital forcing. J. Geophys. Res. Atmos. 107, 3-7 (2002).

88. Timm, O., Timmermann, A., Abe-Ouchi, A., Saito, F. \& Segawa, T. On the definition of seasons in paleoclimate simulations with orbital forcing. Paleoceanography 23, PA2221 (2008).

89. Scargle, J. D. Studies in astronomical time series analysis. II-Statistical aspects of spectral analysis of unevenly spaced data. Astrophys. J. Part 1263 , 835-853 (1982).

90. Andres, M. et al. Mean structure and variability of the Kuroshio from northeastern Taiwan to southwestern Japan. Oceanography 28, 84-95 (2015).

91. Ichikawa, H. \& Beardsley, R. C. The current system in the yellow and East China Seas. J. Oceanogr. 58, 77-92, https://doi.org/10.1023/A:1015876701363 (2002).

92. Balmaseda, M. A., Mogensen, K. \& Weaver, A. T. Evaluation of the ECMWF ocean reanalysis system ORAS4. Q. J. R. Meteorol. Soc. 139, 1132-1161 (2013).

93. Schneider, U. et al. GPCC full data reanalysis version 6.0 at $2.5^{\circ}$ : monthly land-surface precipitation from rain-gauges built on GTS-based and historic data. https://doi.org/10.5676/DWD_GPCC/FD_M_V7_250 (2011).

\section{Acknowledgements}

This research used samples provided by the Integrated Ocean Drilling Program (IODP). This research was supported by NSF OCE-1435266 and -1129408 to S. Clemens; JSPS KAKENHI Grant JP15K21656 to Y. Kubota; Korea Meteorological Industry Promotion Agency, KMI2018-03910 to K.E. Lee; NSF-AGS-1810682 and NSFC41630527 to Z. Liu; Institute of Geosciences, Kiel University funding to A. Holbourn and W. Kuhnt; NNSF of China-41690115 to G. Chen; and ONR N00014-17-1-2393 to Fox-Kemper. We acknowledge the helpful comments, criticisms, and suggestions from two anonymous reviewers as well as reviewer Jess Tierney.

\section{Author contributions}

S.C., A.H., Y.K., and K.E.L. designed this study. S.C and A.H. carried out stable oxygen isotopic analyses on planktonic and benthic foraminifers respectively. Y.K. and K.E.L. carried out sea surface temperature analyses using $\mathrm{Mg} / \mathrm{Ca}$ and $\mathrm{U}^{\prime}{ }_{37}$, respectively. Z.L. and G.C. carried out time-dependent modeling using the Community Climate System Model version 3.5. A.N. and B.F.-K. conducted comparison of model and modern precipitation in the EAM region.

\section{Additional information}

Supplementary Information accompanies this paper at https://doi.org/10.1038/s41467018-05814-0.

Competing interests: The authors declare no competing interests.

Reprints and permission information is available online at http://npg.nature.com/ reprintsandpermissions/

Publisher's note: Springer Nature remains neutral with regard to jurisdictional claims in published maps and institutional affiliations.

(c) (i) Open Access This article is licensed under a Creative Commons Attribution 4.0 International License, which permits use, sharing, adaptation, distribution and reproduction in any medium or format, as long as you give appropriate credit to the original author(s) and the source, provide a link to the Creative Commons license, and indicate if changes were made. The images or other third party material in this article are included in the article's Creative Commons license, unless indicated otherwise in a credit line to the material. If material is not included in the article's Creative Commons license and your intended use is not permitted by statutory regulation or exceeds the permitted use, you will need to obtain permission directly from the copyright holder. To view a copy of this license, visit http://creativecommons.org/ licenses/by/4.0/.

(C) The Author(s) 2018 